\title{
含 $\mathrm{Va}$ 族 $\mathrm{Si}-\mathrm{Ce}$ 型触媒上エチルベンゼンの 酸化脱水素によるスチレンの合成
}

\author{
早川 孝*, 竹平 勝臣*, 石川 敏夫*
}

\begin{abstract}
$\mathrm{Si}-\mathrm{Ce}-X$ 型 $(X: \mathrm{P}, \mathrm{As}, \mathrm{Bi}$ または $\mathrm{Sb})$ 酸化物上エチルベンゼンの酸化脱水素で, 接触活性に対する $\mathrm{Va}$ 族の 効果を調べだ。反応は常圧固定床流通式, $480^{\circ} \mathrm{C}$ で行った。シリカや $\mathrm{Si}-\mathrm{Ce}$ 二元触媒でもスチレンは生成したが, 収率や選択率は低かった。 $\mathrm{Si}-\mathrm{Ce}$ 二元系触媒に Sb を添加すると活性は著しく低下したが，スチレンの選択率は極め て高かった。触媒組成を変化させたところ, $\mathrm{Si}: \mathrm{Ce}: \mathrm{Sb}=1: 1: 1$ でスチレン収率 $44.0 \%$, 同選択率 $87.0 \%$ が得 られ, 他に酸化炭素以外の生成物はこん跡程度であった。この触媒上では長時間にわたって反応に変化が見られた。 触媒上に析出した炭素質はエチルベンゼンの酸化脱水素能を有し，スチレンを生成すると思われた。
\end{abstract}

\section{1. 序論}

エチルベンゼンの脱水素は, 工業的なスチレン製造方法とし て現在広く採用されている。しかしこの反応は吸熱反応であ り，また平衡の制約からェチルベンゼンは低い濃度での操業を 余儀なくされ，しかも多量の過熱水蒸気を必要とする極めてェ ネルギー多消費型の製造方法である。これに対して酸素存在下 で反応を行ら酸化脱水素反応は省エネルギー的な方法として注 目され, その研究報告もかなりある。当初は共役二重結合の類 似性から脂肪族オレフィンの酸化脱水素に 高活性を示す Mo$B \mathrm{i}$ 複合酸化物等の触媒の適用が検討されたが良い結果は得ら れていない1)。その後, 特許請求されている触媒も Mo-Bi 系 と異なり, 例光ば $\mathrm{Zn}-\mathrm{P}-\mathrm{Si}^{2)}, \mathrm{Sn}-\mathrm{P}-\mathrm{Al}^{3)}, \mathrm{Cr}-\mathrm{Ni}-\mathrm{Al}^{4)}, \mathrm{P}-$ $\mathrm{Al}^{5)}, \mathrm{Ce}-\mathrm{P}^{6)}$ 等の複合酸化物, あるいは気相中にハロゲンや $\mathrm{SO}_{2}$ を共存させて使用する $\mathrm{Pd}-\mathrm{KBr}-\mathrm{Al}^{7)}$ や $\mathrm{CaNiPO}_{4}{ }^{8)}$ 等が举 ゲられる。反応機作については，Sn-P または $\mathrm{Na}-\mathrm{SiO}_{2} \cdot \mathrm{Al}_{2} \mathrm{O}$ 上でェチルベンゼンの吸着や酸素の活性化を触媒の酸・塩基性 と関連させて検討した Murakami らの研究9),10)，あるいは アルミナ上に析出した炭素質のエチルベンゼン酸化脱水素能を 見い出し, ある強度範囲内の酸点に析出した炭素質がスチレン 合成能を有することを Alkazov らが発表11) 15) している。さ らに後者の研究では活性炭を用いてェチルベンゼンの酸化を行 い, 非定常状態ではあるがかなり高いスチレン収率が得られて

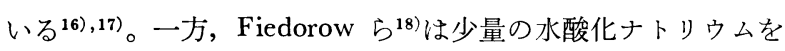
添加したアルミナ触媒上に析出する炭素質について検討し, 常 磁性種がスチレン合成の活性種であろうと推定している。その 他, 八ロゲン修飾担持 $\mathrm{Pd}$ 触媒で $\mathrm{Pd}$ 自身の水素引き抜き能に 注目した研究 ${ }^{19)}, \mathrm{Mo}-\mathrm{Sn}$ 触媒 ${ }^{20)}$ や酸化ウラン系触媒 ${ }^{21)}$ の触媒 構造と活性の関連性についての研究, さらには Ni-W 上で反 応機構について調べた Cortes ら ${ }^{22)}$ の研究がある。

本研究では, エチルベンゼンの酸化脱水素によるスチレン合 成に $\mathrm{Si}-\mathrm{Ce}-\mathrm{Sb}$ 系酸化物が良好な活性を示すことを見い出し 23), さらにその活性点について 1-ブテンの酸化脱水素活性と 比較しつつ検討した結果を報告する。

昭和 57 年 3 月 24 日受理

* 化学技術研究所 (305 茨城県筑波郡谷田部町東 1-1)

\section{2. 実験 \\ $2 \cdot 1$ 触媒の調製法}

主として Mo-Ce- $X, \mathrm{Si}-\mathrm{Ce}-X$ 型酸化物触媒 $(X: \mathrm{P}, \mathrm{As}$, $\mathrm{Sb}, \mathrm{Bi})$, さらに一部の反応で数種の二元系や $\mathrm{Si}$ 単元触媒を使 用した。

原料のモりブデン酸, 酸化セリウム $(\mathrm{N})$, ピロヒ酸 $(\mathrm{V})$, リン酸, 硝酸ビスマス, 五酸化アンチモンは試薬特級を, また コロイド状シリカは日産化学製スノーテックスを使用した。所 定量の原料と水を湯浴上の蒸発皿に入れ, 加熱混練しながら乾 固後 $100^{\circ} \mathrm{C}$ で一昼夜乾燥させ, さらに $500^{\circ} \mathrm{C}$ で $3 \sim 4$ 時間 焼成した。このものを粉研, ふるい別して 30〜40 メッシュ粒 分のものを反応に供した。ただし Mo-Bi 二元触媒は既報 ${ }^{24)} の$ 硝酸酸性下共沈法で作った。触媒は組成金属の原子記号で表し カッコの中に原子比を示した。ただし，金属種が等量の場合は 原子比の記述を一部省いた。

\section{2 反応方法}

反応は常圧固定床触媒による流通法によって行った。エチル ベンゼンと一部の実験で用いた水は反応管の上部に連結された 蒸発器 $\left(150^{\circ} \mathrm{C}\right)$ にマイクロフィーダーで注入した。反応管は 内径 $10 \mathrm{~mm}$ のステンレス製で外径 $2 \mathrm{~mm}$ の熱電対保護管を軸 方向に内装している。原料混合ガスはエチルベンゼンの供給速 度を $27 \mathrm{mmol} / \mathrm{hr}$ と一定にし, エチルベンゼン: 酸素=1:1 たは $1: 2$ となるように空気量を調節した。一部の実験では窒 素や水蒸気も混入させた。触媒使用量は 1 または $3 \mathrm{ml}, \mathrm{GHSV}$ $=1,300 \sim 6,500 \mathrm{hr}^{-1}$, 反応温度は $480^{\circ} \mathrm{C}$ である。液状の生成 物はメタノール・ドライアイスで冷却したトラップにより捕集 した。また1ーブテン酸化の場合は空気中 1 -ブテン濃度 $17 \%$ (1-ブテン: 酸素 $=1: 1)$ のガスを原料として, 温度 $470^{\circ} \mathrm{C}$, 触媒使用量 $1 \mathrm{ml}, \mathrm{GHSV}=4,000 \mathrm{hr}^{-1}$ で反応を行った。

\section{3 分析方法}

反応原料拈よび水以外の生成物はすべてガスクロ法により分 析した。エチルベンゼン，スチレン，ベンゼンおよびベンズア ルデヒドの分析用カラムはアピエゾングリース L $(4 \mathrm{~m}, 135$ $\left.{ }^{\circ} \mathrm{C}\right)$ を, また安息香酸用にはフェニルメチルシリコン $(5 \mathrm{~m}$, $180^{\circ} \mathrm{C}$ ) を用いた。なおェチルベンゼン酸化の場合, これらの 物質と酸化炭素の生成以外にトルェンや未確認物質のピークが 
認められたが，いずれも極めて微量であったため反応の結果の 計算では無視した。1-ブテン，2-ブテン，ブタジェンおよび 二酸化炭素の分析にはジメチルスルフォラン (7 m, 室温) を 用い, 一酸化炭素, 酸素および窒素にはモレキュラーシーブ $13 \mathrm{X}(1 \mathrm{~m}$, 室温) を用いた。収率や選択率は炭素基準で計算し た。本研究では触媒の酸化活性に注目したので便宣上生成した 2-ブテンは未反応オレフィンとして計算した。

触媒の酸性度は松崎ら ${ }^{25}$ の n-ブチルアミン 滴定法により 測 定した。用いた指示薬は Benzalacetophenone $(\mathrm{PKa}=-5.6)$ ， Dicinnamalacetone $(\mathrm{PKa}=-3.0), \quad$ 4-Benzeneazodiphenylamine $(\mathrm{PKa}=1.5)$, 4-Benzeneazo-1-Naphthylamine (PKa= 4.0) および Bromothymolblue $(\mathrm{PKa}=7.1)$ の 5 種類である。 触媒の比表面積はマイクロメリティックス社製, 自動表面積 測定装置で窒素吸着法により測定した。

反応使用後の触媒中の炭素々水素の量は, 次の手順で測定し た。反応終了後, 触媒を窒素ガス流通下で泠却し, その一部を $300^{\circ} \mathrm{C}, 10^{-4}$ Torr で 1 時間脱気して付着水分を取り除き，7 $\sim 8 \mathrm{mg}$ を精ひょうして元素分析装置（島津製・CHN-1 A) にかけた。この装置の燃焼温度は $800^{\circ} \mathrm{G}$ で，燃焼ガスはさら に四三酸化コバルトで酸化 $\left(800^{\circ} \mathrm{C}\right)$ され, 試料中の水素と炭 素はそれぞれ水と二酸化炭素として TCD で検出されるように なっている。また同様の分析を室温で脱気した触媒についても 行った。

脱気した触媒の IR 吸収スペクトルの測定は $\mathrm{KBr}$ 錠剂法に より行った。

\section{3. 結果および考察}

\section{$3.1 \mathrm{Mo}-\mathrm{Ce}-\boldsymbol{X}$ 型触媒上の反応}

まず，高い $n$-ブテン酸化脱水素能を示す $\mathrm{Mo}-\mathrm{Ce}-X$ 型触 媒上での 1-ブテンとエチルベンゼンの反応結果を Tables 1 および 2 に示す。1-ブテン酸化では $X$ 成分が $\mathrm{Bi}$ の場合にブタ ジェンの収率は極めて高く，As もかなりの効果を示すが，Sb と P は低い。一方同じ触媒上でェチルベンゼンを酸化するとス
チレン以外にベンゼン，ベンズアルデヒドおよび安息香酸がか なり生成する。両反応の結果を比較すると, ブタジェン収率の 高い Bi やAsを含有した触媒でのスチレン収率は著しく低下 している。しかし Pや Sb の添加では逆にスチレン収率がブタ ジェン収率を上回っている。このことはスチレン, ベンゼン, ベンズアルデヒドおよび安息香酸の合計収率とブタジェン収率 を比較した場合でも同様である。これらの事実は Mo-Ce- $X$ 型触媒のアリル型酸化に対する活性序列が，同触媒上でのエチ ルベンゼン酸化においては成立していないことを示しており， 興味深い。

\section{$3 \cdot 2$ 単元および二元触媒による反応}

アルミナ上でのエチルベンゼンの酸化脱水素についてはすで に報告されている11)ので，ここではまずシリカについて調べ た。Table 3 に示したように, シリカは単独でェチルベンゼン に対する酸化能を持っている。そこで通常は担体として用いら れるシリカを触媒成分として使用することにした。二元触媒と して Si-Ce と As-Ce について実験を行い，比較例としての Mo-Bi による反応の結果とともに Table 3 に示した。 $\mathrm{Si}-\mathrm{Ce}$ 触媒での酸素転化率は高く，またスチレンも生成するがその選 択率はあまり高くない。一方, As-Ce 触媒ではスチレン収率 は低いが同選択率は高い。また高いブタジェン合成能を示す Mo-Bi 触媒は，収率 $17.5 \%$ でスチレンを生成するがベンゼ ソやベンズアルデヒドもかなりできる。前節の三元触媒でも同

Table 1 Results of Oxidative Dehydrogenation of 1-Butene over the Mo-Ce- $X$ Type Catalyst

\begin{tabular}{|c|c|c|c|c|}
\hline \multirow{2}{*}{ Catalyst } & \multicolumn{2}{|c|}{ Conversion (\%) } & \multicolumn{2}{|c|}{ Yield (Selectivity) $(\%)$} \\
\hline & Oxygen & Butene & Butadiene & $\mathrm{CO}+\mathrm{CO}_{2}$ \\
\hline Mo-Ce-P & 6.3 & 3.4 & $1.8(52.9)$ & $1.6(47.1)$ \\
\hline Mo-Ce-As & 48.2 & 31.4 & $24.6(78.3)$ & $6.8(21.7)$ \\
\hline $\mathrm{Mo}-\mathrm{Ce}-\mathrm{Sb}$ & 33.6 & 13.3 & $9.2(69.2)$ & $4.1(30.8)$ \\
\hline Mo-Ce-Bi & 75.1 & 82.5 & $75.8(91.9)$ & $6.7(8.1)$ \\
\hline
\end{tabular}

Reaction temperature : $470^{\circ} \mathrm{C}$, Catalyst : $1 \mathrm{ml}$, GHSV : $4,000 \mathrm{hr}^{-1}, \quad 1$-Butene $: \mathrm{O}_{2}=1: 1$

Table 2 Results of Oxidative Dehydrogenation of Ethylbenzene over the Mo-Ce- $X$ Type Catalyst

\begin{tabular}{|c|c|c|c|c|c|c|c|c|}
\hline \multirow{2}{*}{ Catalyst } & \multicolumn{2}{|c|}{ Conversion $(\%)$} & \multicolumn{6}{|c|}{ Yield (Selectivity) (\%) } \\
\hline & Oxygen & $\mathrm{Eb}$ & St & $\mathrm{Bz}$ & B-ald & B-acid & Totala) & $\mathrm{CO}+\mathrm{CO}_{2}$ \\
\hline $\mathrm{Mo}-\mathrm{Ce}-\mathrm{P}$ & 26.4 & 12.0 & $5.2(43.4)$ & trace & $1.1(9.2)$ & $1.3(10.8)$ & $7.6(63.3)$ & $4.4(36.7)$ \\
\hline Mo-Ce-As & 74.1 & 30.3 & $8.4(27.7)$ & $0.8(2.6)$ & $6.2(20.5)$ & $3.5(11.6)$ & $18.9(62.4)$ & $11.4(37.6)$ \\
\hline $\mathrm{Mo}-\mathrm{Ce}-\mathrm{Sb}$ & 66.5 & 32.7 & $12.1(37.0)$ & $0.6(1.8)$ & $6.0(18.3)$ & $1.4(4.3)$ & $20.1(61.5)$ & $12.6(38.5)$ \\
\hline Mo-Ce-Bi & 79.0 & 43.2 & $16.1(37.3)$ & $4.6(10.6)$ & $5.4(12.5)$ & $0.8(1.9)$ & $26.9(62.3)$ & $16.3(37.7)$ \\
\hline
\end{tabular}

Reaction temperature : $480^{\circ} \mathrm{C}$, Gatalyst : $3 \mathrm{ml}$, GHSV :2, $300 \mathrm{hr}^{-1}, \quad \mathrm{~Eb}: \mathrm{O}_{2}: \mathrm{N}_{2}=1: 2: 7.4$

$\mathrm{Eb}$-Ethylbenzene, St-Styrene, Bz-Benzene, B-ald-Benzaldehyde, B-acid-Benzoic acid

a) Total $=\mathrm{St}+\mathrm{Bz}+\mathrm{B}$-ald $+\mathrm{B}$-acid

Table 3 Results of Oxidative Dehydrogenation of Ethylbenzene over $\mathrm{SiO}_{2}$ and Binary Oxide

\begin{tabular}{|c|c|c|c|c|c|c|c|}
\hline \multirow{2}{*}{ Catalyst } & \multicolumn{2}{|c|}{ Conversion $(\%)$} & \multicolumn{5}{|c|}{ Yield (Selectivity) (\%) } \\
\hline & Oxygen & $\mathrm{Eb}$ & St & $\mathrm{Bz}$ & B-ald & B-acid & $\mathrm{CO}+\mathrm{CO}_{2}$ \\
\hline $\begin{array}{l}\mathrm{Si} \\
\mathrm{Si}-\mathrm{Ce} \\
\mathrm{As}-\mathrm{Ce} \\
\mathrm{Mo}-\mathrm{Bi}\end{array}$ & $\begin{array}{l}59.4 \\
94.4 \\
21.9 \\
74.6\end{array}$ & $\begin{array}{l}16.5 \\
33.6 \\
13.2 \\
44.1\end{array}$ & $\begin{aligned} 6.5 & (39.4) \\
12.5 & (37.2) \\
8.5 & (64.4) \\
17.5 & (39.7)\end{aligned}$ & $\begin{array}{ll}0.2(1.2) \\
0.4(1.2) \\
0.2(1.5) \\
3.7(8.4)\end{array}$ & $\begin{array}{l}0.3(1.8) \\
\text { trace } \\
0.3(2.3) \\
5.2(11.8)\end{array}$ & $\begin{array}{c}\text { trace } \\
\text { trace } \\
\text { trace } \\
0.2(0.5)\end{array}$ & $\begin{array}{rr}9.5 & (57.6) \\
20.7 & (61.6) \\
4.2 & (31.8) \\
17.5 & (39.7)\end{array}$ \\
\hline
\end{tabular}

Reaction temperature $: 480^{\circ} \mathrm{C}$, Catalyst : $3 \mathrm{ml}$, GHSV : 2, $300 \mathrm{hr}^{-1}, \quad \mathrm{~Eb}: \mathrm{O}_{2}: \mathrm{N}_{2}=1: 2: 7.4$ 
Table 4 Results of Oxidative Dehydrogenation of Ethylbenzene over the Si-Ce- $X$ Type Catalyst

\begin{tabular}{|c|c|c|c|c|c|c|c|}
\hline \multirow{2}{*}{ Catalyst } & \multicolumn{2}{|c|}{ Conversion $(\%)$} & \multicolumn{5}{|c|}{ Yield (Selectivity) $(\%)$} \\
\hline & Oxygen & $\mathrm{Eb}$ & St & $\mathrm{Bz}$ & B-ald & B-acid & $\mathrm{CO}+\mathrm{CO}_{2}$ \\
\hline $\begin{array}{l}\mathrm{Si}-\mathrm{Ce}-\mathrm{P} \\
\mathrm{Si}-\mathrm{Ce}-\mathrm{As} \\
\mathrm{Si}-\mathrm{Ce}-\mathrm{Sb} \\
\mathrm{Si}-\mathrm{Ce}-\mathrm{Bi}\end{array}$ & $\begin{array}{l}93.0 \\
94.8 \\
93.9 \\
31.6\end{array}$ & $\begin{array}{l}44.5 \\
50.6 \\
50.6 \\
19.2\end{array}$ & $\begin{array}{ll}23.8 & (53.5) \\
29.6 & (58.5) \\
44.0 & (87.0) \\
11.9 & (62.0)\end{array}$ & $\begin{array}{c}0.7(1.6) \\
1.9(3.8) \\
\text { trace } \\
\text { trace }\end{array}$ & $\begin{array}{c}0.1(0.2) \\
\text { trace } \\
\text { trace } \\
\text { trace }\end{array}$ & $\begin{array}{l}\text { trace } \\
\text { trace } \\
\text { trace } \\
\text { trace }\end{array}$ & $\begin{array}{rr}19.9(44.7) \\
19.1(37.7) \\
6.6(13.0) \\
7.3(38.0)\end{array}$ \\
\hline
\end{tabular}

Reaction temperature : $480^{\circ} \mathrm{C}$, Catalyst $: 3 \mathrm{ml}$, GHSV : 2, $300 \mathrm{hr}^{-1}, \quad \mathrm{~Eb}: \mathrm{O}_{2}: \mathrm{N}_{2}=1: 2: 7.4$

Table 5 Results of Oxidative Dehydrogenation of 1-Butene over the $\mathrm{Si}-\mathrm{Ce}-X$ Type Gatalyst

\begin{tabular}{l|rr|rr}
\hline \multirow{2}{*}{ Catalyst } & \multicolumn{2}{|c}{ Conversion (\%) } & \multicolumn{2}{c}{ Yield (Selectivity) $(\%)$} \\
\cline { 2 - 5 } & \multicolumn{2}{|c|}{ Oxygen } & Butene & \multicolumn{2}{c}{ Butadiene } & \multicolumn{1}{c}{$\mathrm{CO}+\mathrm{CO}_{2}$} \\
\hline $\mathrm{Si}-\mathrm{Ce}-\mathrm{P}$ & 93.2 & 28.1 & $11.7(41.6)$ & $16.4(58.4)$ \\
$\mathrm{Si}-\mathrm{Ce}-\mathrm{As}$ & 93.7 & 38.0 & $22.5(59.2)$ & $15.5(40.8)$ \\
$\mathrm{Si}-\mathrm{Ce}-\mathrm{Sb}$ & 64.9 & 25.6 & $12.0(46.9)$ & $13.6(53.1)$ \\
$\mathrm{Si}-\mathrm{Ce}-\mathrm{Bi}$ & 78.1 & 23.7 & $9.4(39.7)$ & $14.3(60.3)$ \\
\hline
\end{tabular}

Reaction temperature $: 470^{\circ} \mathrm{C}$, GHSV $: 4,000 \mathrm{hr}^{-1}$, Catalyst : $1 \mathrm{~m} l, \quad 1$-Butene $: \mathrm{O}_{2}=1: 1$

様であるが，エチルベンゼン酸化でベンズアルデヒドや安息香 酸が生成するのは既報のように $\left.{ }^{20}\right) \mathrm{Mo}$ 含有触媒の特徵のようで ある。

\subsection{Si-Ce- $\boldsymbol{X}$ 型}

前節の結果から, $\mathrm{Si}$ と $\mathrm{Ce}$ および As から成る複合酸化物 のエチルベンゼンに対する酸化能が期待できたので, $\mathrm{Si}$ と $\mathrm{Ce}$ および Va 族の As，P，Bi または Sbを添加した三元触媒で エチルベンゼンの酸化を行った。また比較のためにそれらの触 媒を1ーブテンの酸化にも使用した。Tables 4 および 5 にそ れらの結果を示した。Mo 系触媒 (Table 2) と異なり, この $\mathrm{Si}-\mathrm{Ce}-X$ 型触媒ではスチレンと酸化炭素以外の生成物の量は 極めて少ない。特に $\mathrm{Si}-\mathrm{Ce}-\mathrm{Sb}$ 触媒では酸化炭素の選択率が 低くスチレン収率が高いので，この触媒はスチレン合成触媒と してかなり良好なものと思われる。比較のために行ったブテン 酸化では Table 5 からわかるように, いずれの触媒も部分酸 化活性は低い。なおこの触媒系での 1-ブテンから 2-ブテンへ の転化率は $X$ が P場合で $51.6 \%$, 以下 $\mathrm{As}, \mathrm{Sb}, \mathrm{Bi}$ の順に $9.3 ， 6.1$ および $5.7 \%$ となった。

\section{4 触媒組成比の影響}

これまでは触媒の金属原子比がすべて等量のものを用いて活 性試験を行ってきたが，前節で述べたように Si-Ce-Sb 触媒 が高いスチレン合成能を示すことが分ったので, 次に $\mathrm{Si}-\mathrm{Ce}$ 二元および $\mathrm{Si}-\mathrm{Ce}-\mathrm{Sb}$ 三元触媒の組成比の影響を検討した。

Fig. 1 はシリカに Ce を添加した場合であるが，反応条件は 異なっているものの, 少量の $\mathrm{Ce}$ 添加でスチレンの生成率と選 択率は上昇することがわかる。一方, 酸化炭素収率には大差な い。なお $\operatorname{Si-Ce}(1: 1)$ 触媒の活性が Table 3 の数值と異なっ ているのは GHSV および分圧の相違によるものと思われる。 次に $65 \%$ 程度のスチレン選択率を示した $\mathrm{Si}-\mathrm{Ce}(1: 0.25)$ 触 媒に Sb を添加すると(Fig. 2), 約 $3 \%$ の Sb 添加で酸化活性 は極端に低下するが, スチレンの選択率は $97 \%$ と非常に高い值 を示した。 $\mathrm{Sb}$ 含量が $3 \%$ 以上では活性は低いが，原料転化率 やスチレンの収率は若干上昇しているようであり，スチレン選

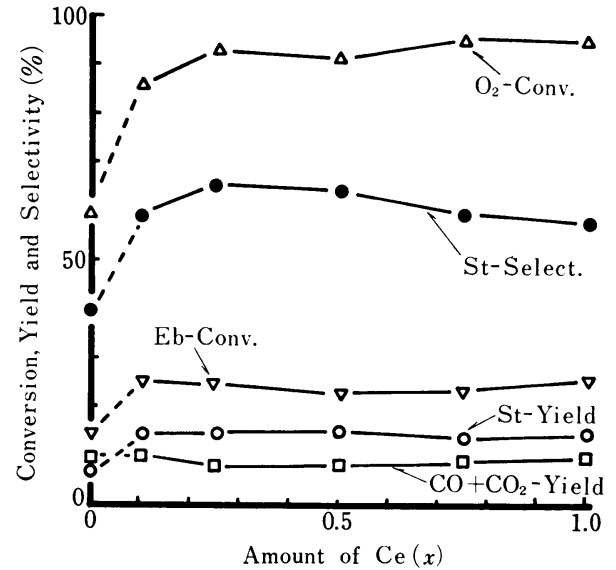

Reaction temperature : $480^{\circ} \mathrm{C}$, Catalyst : $1 \mathrm{~m} l$, GHSV : $6,500 \mathrm{hr}^{-1}, \mathrm{~Eb}: \mathrm{O}_{2}: \mathrm{N}_{2}=1: 1: 8$

The reaction result over $\mathrm{SiO}_{2}$ was quoted from the value in Table 3 .

Fig. 1 The Effect of Ce Content on the Catalytic Properties of the $\mathrm{Si}-\mathrm{Ce}(1: x)$ Oxide in the Oxidative Dehydrogenation of Ethylbenzene

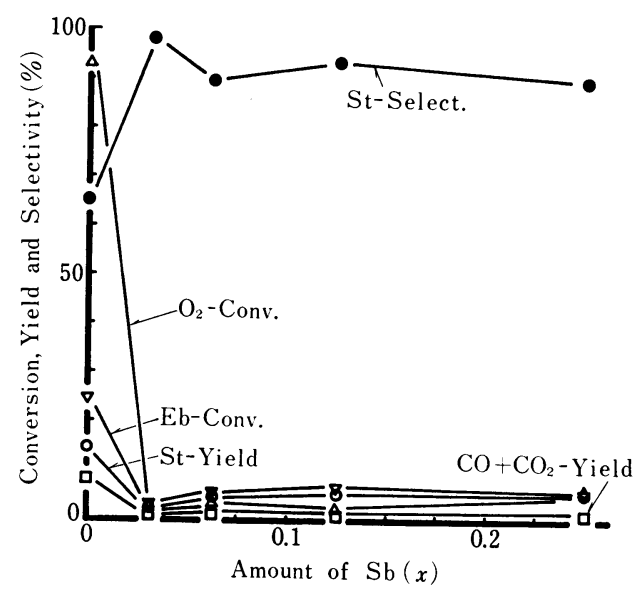

Reaction temperature : $480^{\circ} \mathrm{C}$, Catalyst : $1 \mathrm{ml}$, GHSV : 6, $500 \mathrm{hr}^{-1}, \mathrm{~Eb}: \mathrm{O}_{2}: \mathrm{N}_{2}=1: 1: 8$

Fig. 2 The Effect of Sb Content on the Catalytic Properties of the $\mathrm{Si}-\mathrm{Ce}-\mathrm{Sb}(1: 0.25: x)$ Oxide in the Oxidative Dehydrogenation of Ethylbenzene

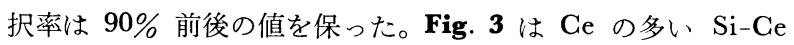
(1:1) 触媒に $\mathrm{Sb}$ を添加した触媒について調べた結果である が，前記 $\mathrm{Si}-\mathrm{Ce}(1: 0.25)$ 触媒ほどの活性低下は見られないも のの, $\mathrm{Sb}$ 添加量と活性との関係は Fig. 2 とほぼ同様な傾向 
を示した。即ちスチレン選択率については Si-Ce(1:0.25) 触 媒と同様に高い值が保たれた。以上の結果から次のことが言え る。 $\mathrm{Si}-\mathrm{Ce}$ 二元触媒の高い酸化活性は Sb 添加により抑制さ れ，この効果は特に完全酸化に対して顕著であるが $\mathrm{Ce}$ 量の少 ない場合は部分酸化能をも抑制してしまう。しかし Fig. 3 に 見られるように, $\mathrm{Si}-\mathrm{Ce}-\mathrm{Sb}(1: 1: 1)$ 触媒は $\mathrm{Sb}$ 量が多いにも かかわらず酸化活性は他の同系触媒よりも高く，従って Sb 添 加効果は一義的なものではないと思われる。

\section{5 触媒活性の経時変化および水の影響}

これまでに用いた Mo-Ce- $X$ 型, $\mathrm{Si}$ 単元および $\mathrm{Si}-\mathrm{Ce}$ 二 元触媒等を用いた場合には，反応開始後 $2 \sim 3$ 時間以内に活性 はほぼ定常状態に達する。しかし $\mathrm{Si}-\mathrm{Ce}-X$ 型触媒では $X$ が Bi 以外の場合にはかなり長時間にわたって 経時変化があり, 原料転化率や生成率は徐々に上昇する。その最も顕著な例が $\mathrm{Si}-\mathrm{Ce}-\mathrm{Sb}(1: 1: 1)$ 触媒である。Fig. 4 にはエチルベンゼン 濃度を变えて実験をした結果を示してあるが，図からわかるよ らにスチレンの選択率は最初からほぼ一定で, 一方転化率や収 率が定常状態に達するまでには 20 時間もかかる。ただしここ でIの部ではエチルベンゼンの注入量は他の場合と同じである が，IIの部のエチルベンゼンと空気の混合ガスを窒素で希釈し たものを原料ガスに用いたので，I の部の GHSV は 2,400 $\mathrm{hr}^{-1}$ となっている。 II のようなエチルベンゼン濃度が高くて GHSV が小さな場合には定常状態に達する時間は 10 時間程 度であった。而はェチルベンゼンと空気および水蒸気の混合ガ スを原料とした場合である。図からわかるようにスチレンの収 率と選択率は若干上昇している程度で水蒸気の添加効果として 特筆すべきものはない。

この様に経時変化が大きいことや，反応途中でェチルベンゼ ンの注入を止めると直後に触媒床の温度が $10 \sim 15^{\circ} \mathrm{C}$ 上昇する こと,さらにェチルベンゼンの注入を再開するとスチレンの収 率は低下するが徐々に回復し，その間選択率には変化が見られ ないことなどから, 触媒表面は経時的に変化していることが考 えられる。さらに事実, 最初白黄色の触媒が使用後には灰色に

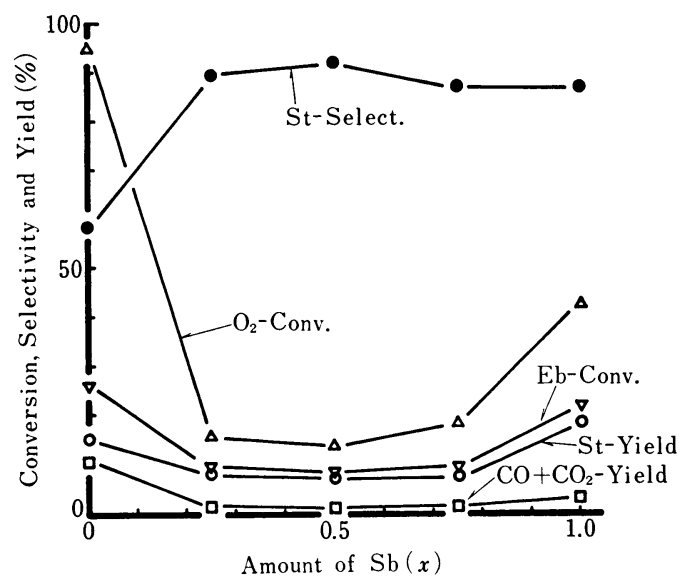

Reaction temperature : $480^{\circ} \mathrm{C}$, Catalyst : $1 \mathrm{ml}$, GHSV : 6, $500 \mathrm{hr}^{-1}, \mathrm{~Eb}: \mathrm{O}_{2}: \mathrm{N}_{2}=1: 1: 8$

Fig. 3 The Effect of $\mathrm{Sb}$ Content on the Catalytic Properties of the $\mathrm{Si}-\mathrm{Ce}-\mathrm{Sb}(1: 1: x)$ Oxide in the Oxidative Dehydrogenation of Ethylbenzene
なっていたことから使用後の触媒の分析を試みることにした。 なお経験的に本研究中で, 使用後の触媒が灰色になる場合と黒 色になる場合があり, 前者はスチレン収率の良好な触媒に多 く, 後者では同収率が低かった。

\section{6 触媒の分析}

まず炭化物質の析出が考兄られるので，使用後の $\mathrm{Si}-\mathrm{Ce}-\mathrm{Sb}$ (1:1:1) 触媒の炭素之水素の量を分析し, Table 6 亿その結 果を示した。表からわかるように触媒上にはかなりの量の炭素 や水素が存在している。Iwasawa ら²6)がポリナフトキノンを 用いてスチレンを高選択率で得ていることから，上記触媒中の 炭素と水素の比をキノン型化合物と比較してみると, 表に示し た様にそれらは近似している。次に脱気処理した使用後の触媒 とエチルベンゼンを含浸した未使用触媒 ${ }^{\dagger 1)}$ IR スペクトルを 測定した (Fig. 5)。使用後の触媒の $1,790 \mathrm{~cm}^{-1}$ 付近の吸 収はキノン型化合物の $\mathrm{C}=\mathrm{O}$ 伸縮振動によるものと思われ，

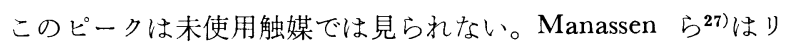
モネン等の脱水素にキノン型化合物を用い，その化合物を再酸

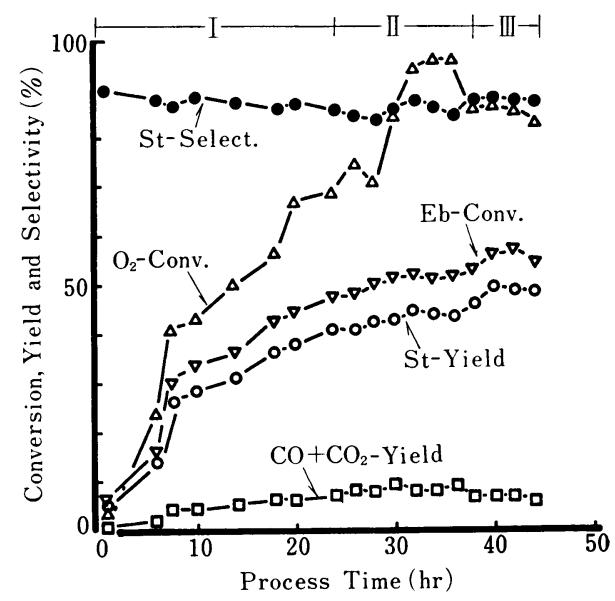

Reaction Condition

Temperature : $480^{\circ} \mathrm{C}$, Catalyst : $3 \mathrm{ml}$ $\mathrm{I}-\mathrm{Eb}: \mathrm{O}_{2}: \mathrm{N}_{2}=1: 1: 8$, GHSV $: 2,200 \mathrm{hr}^{-1}$ II $-\mathrm{Eb}: \mathrm{O}_{2}: \mathrm{N}_{2}=1: 1: 3.7$, GHSV $: 1,300 \mathrm{hr}^{-1}$ III-Eb : $\mathrm{O}_{2}: \mathrm{N}_{2}: \mathrm{H}_{2} \mathrm{O}=1: 1: 3.7: 4.7$, GHSV $2,300 \mathrm{hr}^{-1}$

Fig. 4 The Result of Oxidative Dehydrogenation of Ethylbenzene over the $\mathrm{Si}-\mathrm{Ce}-\mathrm{Sb}(1: 1: 1) \mathrm{Ox}-$ ide Catalyst

Table 6 Amounts of Hydrogen and Carbon on $\mathrm{Si}-\mathrm{Ce}-\mathrm{Sb}(1: 1: 1)$ Catalyst

\begin{tabular}{l|c|c|c}
\hline & $\begin{array}{c}\text { Carbon } \\
(\text { wt } \%)\end{array}$ & $\begin{array}{c}\text { Hydrogen } \\
(\text { wt } \%)\end{array}$ & H/C Ratio \\
\hline Used Catalysta) & 5.79 & 0.22 & 0.038 \\
Used Catalyst $\mathrm{b})$ & 6.35 & 0.36 & 0.057 \\
Ethylbenzene & - & - & $0.104 \mathrm{c})$ \\
Naphthoquinone & - & - & $0.05^{\mathrm{c})}$ \\
Polynaphthoquinone & - & - & $\left.0.033^{\mathrm{c}}\right)$ \\
\hline
\end{tabular}

a) Evacuated at room temperature and 10-4 Torr

b) Evacuated at $300^{\circ} \mathrm{C}$ and $10^{-4}$ Torr

c) Calculated value

†1) ノウ乳鉢中の未使用触媒上へエチルベンゼンを数滴加 えてつぶしたものの一部と臭化カリウムで錠剤を成型し た。 


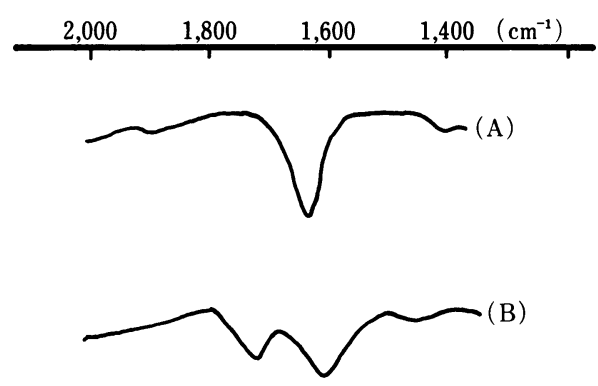

(A) Ethylbenzene was added to the fresh catalyst

(B) The used catalyst was evacuated at $300^{\circ} \mathrm{C}$ and 10-4 Torr

Fig. 5 Infrared Spectra of the Si-Ce-Sb $(1: 1: 1)$ Oxide Catalyst

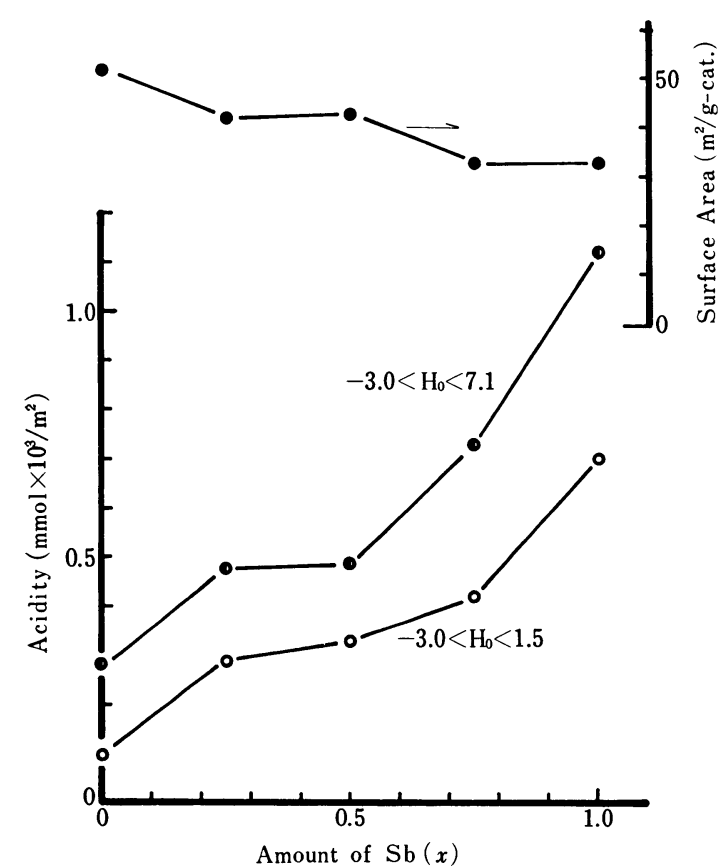

Fig. 6 The Acidity and Surface Area of the Si-Ce-Sb $(1: 1: x)$ Oxide Catalyst

化したものの IR スペクトルを測定しているが，その結果と

Fig. 5 は若干の波数のズレはあるもののほぼ一致している。

$\mathrm{Sb}$ 量の異なる $\mathrm{Si}-\mathrm{Ce}-\mathrm{Sb}(1: 1: X)$ 三元触媒の酸量を測定 し, 触媒の単位表面積当たりに割り付けた酸量と $\mathrm{Sb}$ 量の関係 を各酸強度について Fig. 6 に示した。Dicinnamalacetone $(\mathrm{PKa}=-3.0)$ を酸性色にする触媒はなかった。 $\mathrm{Si}-\mathrm{Ce}-\mathrm{Sb} 三$ 元触媒の活性序列 (Fig. 3) と酸量は同じ傾向を示している。

以上の結果から反応経路について以下のように考皃た。Cortes ら ${ }^{22}$ とよれば Ni-W 酸化物触媒表面のエチルベンゼン酸 化は

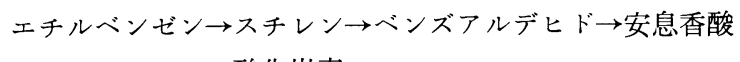

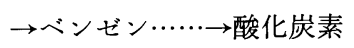

のように反応が進み, 各化合物は触媒上で吸着・脱離を繰り返 している。ただし酸化炭素は各化合物から別の経路で生成する 場合があるので, 他の矢印と区別するために便宣上点線で示し てある。この触媒での主生物はスチレンと酸化炭素で, ベンズ
アルデヒド等の収率がスチレンに対して $1 / 80$ 程度と低いの は，スチレンの安定性によりベンズアルデヒドへの反応速度が 極めて遅いためであると述べ，大部分の酸化炭素の生成には上 記と別な経路を考えている。著者らも短時間で反応が定常状態 になるMo系触媒ではこのような経路を想定している。しかし Cortes ら 22)の結果と異なって，この Mo 系触媒ではかなりの 量のベンズアルデヒドや安息香酸が生成しており，これについ ては触媒がそれらの生成物中に取り込まれる酸素種 ${ }^{28)}$ を保有し ていることによるものと考えた。一方，Mo 系触媒と同じょう に短時間で反応が定常状態になる $\mathrm{Si}-\mathrm{Ce}$ 二元触媒で, ベンズ アルデヒド等がほとんど生成しないのはスチレンの安定性も一 つの原因であろうが，この二元触媒には上述のような酸素種が 存在しないことが大きな原因となっているのではないかと思わ れた。

次に $\mathrm{Si}-\mathrm{Ce}-\mathrm{Sb}$ 三元触媒が，反応初期に酸化活性は低いに もかかわらず，長時間にわたってスチレン収率が徐々に上昇し ている原因を推定した。Si-Ce 二元触媒にくらべて $\mathrm{Si}-\mathrm{Ce}-\mathrm{Sb}$ 三元触媒の酸量が増加していることから，この触媒上で生成し たスチレンは重合しやすく，さらにこの重合物が酸化される過 程でポリナフトキノンと類似な化合物へと变化する。そして触 媒上に蓄積したこの化合物の酸化脱水素能によってスチレンが 生成される。即ち, 次のような反応経路を想定している。

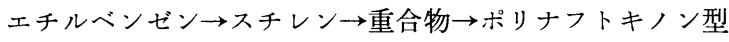

化合物 $\rightarrow$ 酸化炭素

ただし酸化炭素は，前述したように他の経路から生成する場 合も考兄られるで，ここに示した酸化炭素は上記キノン型化 合物から生成するもののみを表すものとし，以下の記述でも同 様である。ここで $\mathrm{Si}-\mathrm{Ce}-\mathrm{Sb}$ 三元触媒は酸化能が弱いため, 反応初期にスチレン生成速度は遅い。一方キノン型化合物の生 成は, 温度や触媒上の酸点および気相中の酸素などに促進され ること。さらに同化合物は後述するような理由から，エチルべ ンゼン存在下では比較的に安定に存在すると考えられることな どにより，同化合物の生成速度は酸化炭素の生成速 度より速 い。しかし気相中にスチレンが脱離してくることから考えて， キノン型化合物の生成速度はスチレン生成速度より遅い。以上 のことから，触媒表面にはキノン型化合物が蓄積することにな る。そしてこのものの量変化が見かけ上なくなるまで, 反応に は経時変化が現れるのであろう。

ポリナフトキノン型の化合物が前述したよらな条件下で安定 な理由については, Iwasawa ら 26 がポリナフトキノン上のエ チルベンゼン酸化脱水素について次のよらな機構を示している ので,

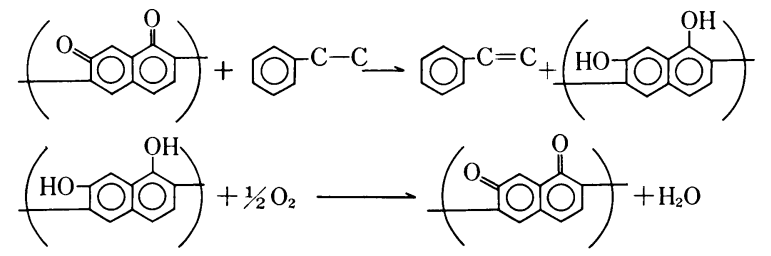

ここで生成したジヒドロキシナフタレンの水素が気相中の酸素 に引き抜かれ，そこにェチルベンゼンが配位すれば，ナフトキ ノンと気相中の酸素の接触は阻害される。本研究での酸化中間 
生成物であるナフトキノン型化合物も同様であるなら，その構 造をかなりの時間保持できると思われる。

\section{References}

1) Adams, C. R., J. Cat., 10, 355 (1968).

2) Japan. 74 41,182.

3) Japan. $7729,301$.

4) Japan. 75 30,061.

5) Japan. $77 \quad 29,299$.

6) Japan. Kokai 74 127,930.

7) Japan. Kokai $7844,525$.

8) U.S. $3,294,856$.

9) Murakami, Y., Iwayama, K., Uchida, H., Hattori, T., Tagawa, T., J. Cat., 71, 257 (1981).

10) Tagawa, T., Hattori, T., Murakami, Y., Syokubai, 21, 319 (1979).

11) Alkhazov, T. G., Lisovskii, A. E., Safarov, M. G., Dadasheva, A. M., Kinetika i Kataliz, 13, 509 (1972).

12) Alkhazov, T. G., Lisovskii, A. E., Safarov, M. G., Lapin, V. B., Kurbanov, N. A., Kinetika $i$ Kataliz, 14, 1182 (1973)

13) Lisovskii, A. E., Alkhazov, T. G., Mamedova, S. A., Kinetika i Kataliz, 16, 1254 (1975).

14) Alkhazov, T. G., Lisovskii, A. E., Kinetika $i$ Kataliz,
17, 434 (1976)

15) Lisovskii, A. E., Kozharov, A. I., Feizullaeva, Sh. A., Alkhazov, T. G., Kinetika i Kataliz, 19, 605 (1978).

16) Kozharov, A. I., Ismailov, Yu. A., Lisovskii, A. E., Alkhazov, T. G., Kinetika $i$ Kataliz, 19, 495 (1978).

17) Lisovskii, A. E., Kozharov A. I., Ismailov, Yu. A., Alkhazov, T. G., Kinetika $i$ Kataliz, 19, 950 (1978).

18) Fiedorow, R., Przystajko, W., Sopa, M., Dalla lana, I. G., J. Cat., 68, 33 (1981).

19) Fujimoto, K., Yamada, J., Kunugi, T., Nippon Kagaku Kaishi, 1977, 523.

20) Araki, M., Nishimura, T., Hayakawa, T., Ishikawa, T., J. Japan Petrol. Inst., 17, 666 (1974).

21) Nozaki, F., Ichikawa, F., Nippon Kagaku Kaishi, 1973, 254.

22) Cortes, A., Seoane, J. L., J. Cat., 34, 7 (1974).

23) Japan. 80 32,692.

24) Ishikawa, T., Hayakawa, T., Bull. Japan Petrol. Inst., 17, 76 (1975).

25) Matsuzaki, I., Fukuda, Y., Kobayashi, T. Kubo, K., Tanabe, K., Syokubai, 11, 211 (1969).

26) Iwasawa, Y., Nobe, H., Ogasawara, S., J. Cat., 31, 444 (1973).

27) Manassen, J., Khalif, Sh., J. Cat., 13, 290 (1969).

28) Akimoto, M., Syokubai, 21, 371 (1979). 


\title{
Summary
}

\section{Oxidative Dehydrogenation of Ethylbenzene to Styrene over Si-Ce Type Oxide Gatalysts Containing Va Group-Elements}

\author{
Takashi Hayakawa*, Katsuomi Takehira* and Toshio Ishikawa*
}

The catalytic activity of the Si-Ce type oxides containing the $\mathrm{Va}$ group-elements for vapor-phase oxidative dehydrogenation of ethylbenzene has been studied. The Mo-Ce- $X$ ( $X$ : the Va group-elements, P, As, $\mathrm{Bi}$ or $\mathrm{Sb}$ ) type oxides have also been used in order to compare their activities with those of the Si-Ce- $X$ type oxides.

The reaction was performed at $480^{\circ} \mathrm{C}$ and at GHSV $1,300 \sim 6,500 \mathrm{hr}^{-1}$ using a gaseous reactant mixture with the ethylbenzene/oxygen molar ratio of 1 or $1 / 2$.

When $\mathrm{SiO}_{2}$ and Si-Ce $(1: 1)$ binary oxide were used as the catalyst, the yield of styrene was $6.5 \%$ and 12.5 $\%$ and its selectivity was $39.4 \%$ and $37.2 \%$, respectively (Table 3). By the addition of a small amount of $\mathrm{Sb}$ component to the $\mathrm{Si}-\mathrm{Ce}(1: 1)$ binary oxide, the selectivity of styrene increased remarkably though the activity decreased. By increasing the amount of $\mathrm{Sb}$ component in the catalyst, the activity increased (Fig. 3). The largest yield of styrene, $44.0 \%$ with selectivity of $87.0 \%$, was obtained by using the $\mathrm{Si}-\mathrm{Ce}-\mathrm{Sb}$ $(1: 1: 1)$ oxide catalyst. In this case, the major products, excluding water, were styrene and carbon

* National Chemical Laboratory for Industry (Yatabemachi-Higashi, Tsukuba-gun, Ibaraki 305) oxides, and the amounts of other products including benzaldehyde were very small (Table 4).

The Mo-Ce- $X$ type oxide showed a high activity for $n$-butene oxidative dehydrogenation which is known to proceed via $\pi$-allyl intermediate (Table 1). When this catalyst was used in the oxidation of ethylbenzene, substantial amounts of benzaldehyde, benzoic acid, and benzene were formed and the yields and selectivitys of styrene were very low (Table 2).

The conversion of ethylbenzene and the yields of styrene over the Si-Ce-Sb $(1: 1: 1)$ oxide catalyst increased during the reaction for $10 \sim 20$ hours, and the selectivity of styrene showed a constant and high value throughout the reaction period (Fig. 4).

Acidity increased with increasing amount of Sb component $(x)$ in the Si-Ce-Sb $(1: 1: x)$ oxide catalyst (Fig. 6). The formation of coke was observed on the $\mathrm{Si}-\mathrm{Ce}-\mathrm{Sb}(1: 1: 1)$ oxide catalyst during the reaction. The IR spectroscopy and elementary analysis of used catalyst suggested that the coke consisted mainly of a polynaphthoquinone-type compound which was considered to be active for the oxidative dehydrogenation of ethylbenzene to styrene.

\section{Keywords}

Cerium oxide, Ethylbenzene, Oxidative dehydrogenation, Styrene 